\title{
Impact of the Internet Using Experience on the Peculiarities of the Internet Texts Understanding
}

\section{Вплив досвіду користування інтернетом на особливості розуміння текстів інтернету}

Nataliia Akimova ${ }^{1}$

Ph.D. in Philology,

Assistant Professor

\author{
Наталія Акімова ${ }^{1}$ \\ кандидат філологічних наук, \\ доцент
}

\section{E-mail: natashashadow8@gmail.com orcid.org/0000-0001-9952-1153}

\section{Kateryna Oleksandrenko ${ }^{2}$}

DSc (Psychology), Professor
Катерина Олександренко ${ }^{2}$ доктор психологічних наук, професор

E-mail: oleksandrenkok@gmail.com orcid.org/0000-0001-9735-3715

${ }^{1}$ Pereiaslav-Khmelnytskyi

Hryhorii Skovoroda State

Pedagogical University

$\triangle$ 30, Sukhomlynskyi Str.,

Pereiaslav-Khmelnytskyi, Kyiv Reg., Ukraine, 08401

\section{${ }^{2}$ Khmelnytskyi National University}

11, Instytutska Str., Khmelnytskyi, Ukraine, 29016

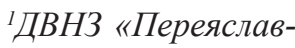
Хмельницький державний педагогічний університет імені Григорія Сковороди» $\triangle$ вул. Сухомлинського, 30, Переяслав-Хмельницький, Київська обл., Україна, 08401

${ }^{2}$ Хмельницьький національний університет

$\triangle$ вул. Інститутська, 11 , Хмельницький, Україна, 29016

Original manuscript received May 09, 2018

Revised manuscript accepted September 15, 2019 


\section{ABSTRACT}

Objective. The article presents the results of the empirical study of the impact of the Internet using experience on the process of the Internet texts understanding.

Materials \& Methods. Different theoretical methods and techniques were used for this purpose: deductive and inductive methods, analysis and synthesis, generalization, systematization. Empirical methods were used for this purpose: experiment (semantic and receptive), method of semantic and pragmatic interpretations, content analysis, subjective scaling procedure. Mathematical methods were used: primary statistics, checks on the normal nature of the data distribution, statistical output, taking into account statistical indicators of fashion and the scope of variation. As well as some interpretive methods that are based on specific principles of systemic, activity, cognitive and organizational approaches.

Results. The author notes that Internet texts understanding is significantly different from the understanding of oral or written texts, since the Internet text is a pragmatically integral electronic document that constructing of conditionally completed text blocks in the form of "windows", that are opened in separate tabs of the browser, the order that depends on hyperlinks and user behavior. The peculiarities of the Internet texts include enhanced dialogue, divisibility, external informativity, reduced connectivity and comprehension, pragmatic and mostly formal integrity, conditional completeness, complicated structural, as well as hybrid and high degree of permeability, multimedia, presentation, inclination to speech game and collective authorship, saturation with neologisms, emoticons and abbreviations, fragmentation, non-compliance with linguistic norms, and the functioning of a special language etiquette.

Conclusions. As a result of empirical research involving 716 respondents from different regions of Ukraine, it was determined that experience has the most significant effect on the understanding process at the reception stage, guiding users' activity and the accuracy of their expectations. Experience contributes to the accuracy of predicting the content of Internet texts by 15,0\%. At the stage of interpretation, the adequacy and completeness of Internet texts interpretation with the accumulation of experience is improved by almost 10,0\%. However, even experienced users were able to correctly interpret only a quarter of the dominant, while random - only a sixth part. Even less important is the experience and Internet activity at the stage of emotional identification, nor the assessment of comprehension, nor the coherence of emotional attitude is almost independent of the Internet using experience. With the accumulation of experience, users evaluate Internet texts more homogeneously, they are easier to realize their own attitude to the Internet texts, it becomes more consistent, however, they underestimate the complexity of Internet texts more than half of the cases, they are also inclined to share texts on the approval and critical like inexperienced readers.

Key words: understanding, internet text, perception, interpretation, emotional identification, experience, internet activity. 


\section{Вступ}

Проблема розуміння тексту є однією з центральних проблем в умовах сучасного інформаційно-комунікаційного суспільства. Вона активно досліджується вченими різних країн та галузей гуманітарної науки (Дейк \& Кинч, 1988; Залевская, 1990; Знаков, 2005; Чепелєва, 1992; Новиков, 1999; Broek, Young, Tzeng \& Linderholm, 1999; Graesser, Wiemer-Hastings \& Wiemer-Hastings, 2001; Cummine, Cribben, Luu et al., 2016; Foucart, Romero-Rivas, Gort \& Costa, 2016; Hubers, Snijders \& Hoop, 2016; Akimoto, Takahashi, Gunji et al., 2017; Bitan, Kaftory, Meiri-Leib et al., 2017; Bosco \& Gabbatore, 2017; Sharon \& Thompson-Schill, 2017; De Freitas, Peruzzi \& Deacon, 2018; Giustolisi, Vergallito, Cecchetto et al., 2018; Hahne, Goldhammer, Kröhne \& Naumann, 2018; Houghton, 2018; Mason, Scrimin, Zaccoletti et al., 2018; Ohadi, Brown, Trub \& Rosenthal, 2018 та ін.). Проте більшість 3 них все ще зосереджують свою увагу навколо традиційних форм текстів: усного чи писемного. Між тим сьогодні все більш значна частина інформаційно-комунікаційних процесів переноситься у середовище інтернету. Отже, все більшого значення набуває проблема розуміння текстів інтернету. Текст інтернету - це не звичайний друкований текст на екрані монітора. Потрапляючи в умови інтернет-середовища текст суттєво видозмінюється, набуваючи специфічних ознак. Таким чином, текст інтернету визначається як прагматично цілісний електронний документ, що складається з умовно завершених текстових блоків у формі «вікон», які розкриваються в окремих вкладках браузера, порядок освоєння яких залежить як від гіперпосилань, так $і$ від поведінки користувача (Щипицина, 2011: 18).

До особливостей текстів інтернету належать такі, як-от: посилені діалогічність, подільність, зовнішня інформативність, послаблені зв'язність і осмисленість, прагматична й переважно формальна цілісність, умовна завершеність, ускладнена структурність, а також гібридність і високий ступінь проникності, мультимедійність, презентативність, схильність до мовної гри і колективного авторства, насиченість неологізмами, емотиконами i скороченнями, фрагментарність, недотримання мовних норм, функціонування особливого мовленнєвого етикету. 
Вплив досвіду користування інтернетом на особливості...

Сучасна людина проводить у віртуальному середовищі значну частину власного життя, та чи допомагає їй набутий там досвід краще розуміти тексти інтернету? Емпіричне дослідження цього питання стало основою написання цієї розвідки.

Мета статmi - здійснити науково обгрунтований аналіз питання значимості досвіду користування інтернетом в процесі розуміння текстів інтернету, на базі емпіричного дослідження визначити, як позначається психологічний вплив досвіду користування інтернетом на результатах розуміння.

\section{Методи та методики дослідження}

Для досягнення зазначеної мети були використані наступні теоретичні методи $i$ методики: а) дедуктивний (як шлях від абстрактного до конкретного); б) індуктивний (як узагальнення фактів); в) аналіз (як шлях від цілого до частин); г) синтез (як шлях від частин до цілого); д) узагальнення (як перехід на більш високу ступінь абстракції шляхом виявлення загальних ознак (властивостей, відношень, тенденцій розвитку і т. п.) предметів); є) систематизація (як зведення розрізнених знань у єдину наукову систему).

Емпіричне дослідження проведене за допомогою таких психологічних та психолінгвістичних методів, як-от: а) експеримент (семантизуючий та рецептивний експерименти); б) метод семантичних і прагматичних інтерпретацій (комплексне тлумачення сенсу висловлювань на основі широкого контексту електронної ситуації концептуальний аналізу тексту (визначення змістовної структури, виокремлення домінант, ключових слів); в) контентаналіз; г) процедура суб'єктивного шкалування (метод абсолютних оцінок). Математична обробка даних здійснювалася за допомогою первинної статистики, перевірки на нормальний характер розподілу даних, статистичного виводу 3 урахуванням таких статистичних показників, як мода та розмах варіації. Також використовувалися інтерпретаційні методи, що грунтуються на конкретних принципах системного, діяльнісного, когнітивного та організаційного підходів. Вони спрямовані на пояснення отриманих результатів 3 точки зору первинних припущень та посилань, інтеграцію отриманих емпіричних закономірностей у єдину наукову картину світу. 


\section{Результати та дискусії}

Вчені зазначають, що накопичення досвіду, в тому числі й щодо мовленнєвої діяльності, має сприяти покращенню цієї діяльності, враховуючи адаптаційний, інтерпретаційний, профілактичний та акумулятивний потенціал. Теоретично збільшення досвіду розуміння, в тому числі й розуміння текстів, має допомагати виділяти домінанти у знайомих текстах, збільшити словниковий запас, що призводить до акумуляції значень; накопичення та узгодження кваліа, сприятиме систематизації смислів та формуванню цілісної картини світу й себе у ньому. Проте в умовах інтернет-середовища процес накопичення досвіду також залежить від специфіки діяльності індивіда, зокрема активності користування інтернетом, частоти його використання, різноманітності видів діяльності, притаманних певній особистстості в інтернеті, вміння користуватися різними специфічними знаряддями (браузерами, пошуковими сервісами, сервісами обміну повідомленнями, соціальними мережами тощо), а також усвідомленістю репрезентації власної особистості в Мережі у формі профілю.

У ході діагностичного експерименту респондентам було запропоновано низку запитань 3 метою визначення рівня їхньої інтернет-активності та, відповідно, досвіду користування інтернетом як наслідку такої активності.

1. Скільки днів на тиждень Ви користуєтеся інтернетом?

2. Скільки годин у день Ви користуєтеся інтернетом?

3. Чи є у Вас профіль в інтернеті?

4. Що Ви зазвичай робите в інтернеті?

5. Які ресурси, як правило, використовуєте? Скільки часу їм приділясте у тиждень?

6. Які браузери Ви використовуєте?

7. Чи доводилося Вам щоось писати в інтернеті? Що саме? Як часто?

Результати опитування було систематизовано $з$ урахуванням регіонального, гендерного та вікового критеріїв. Узагальнення отриманих статистичних даних дозволило розробити систему критеріїв для визначення рівня досвідченості користувачів інтернету. 
Вплив досвіду користування інтернетом на особливості...

Таблиця 1. Критерії визначення рівня інтернет-активності та досвіду користування інтернетом

\begin{tabular}{lccc}
\hline & \multicolumn{3}{c}{ Рівень інтернет-активності та } \\
досвідченості
\end{tabular}

Відповідно до зазначених критеріїв користувачів інтернету за рівнем досвідченості можна поділити на три групи:

3 високим рівнем досвіду та інтернет-активності ( $\mathrm{n}=174,24,3 \%)$,

3 середнім рівнем досвіду та інтернет-активності ( $\mathrm{n}=518,72,3 \%)$,

3 низьким рівнем досвіду та інтернет-активності ( $\mathrm{n}=24,3,4 \%)$.

У ході експериментального дослідження вплив досвіду користування інтернетом на результатах розуміння респондентам було запропоновано такі тексти інтернету:

\section{Текст A}

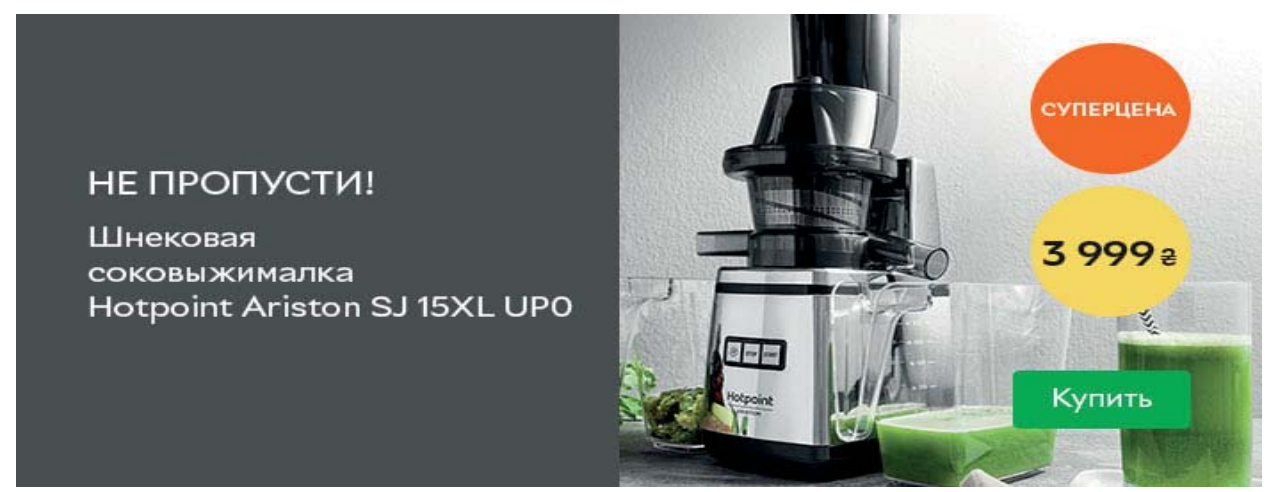




\section{Текст Б}

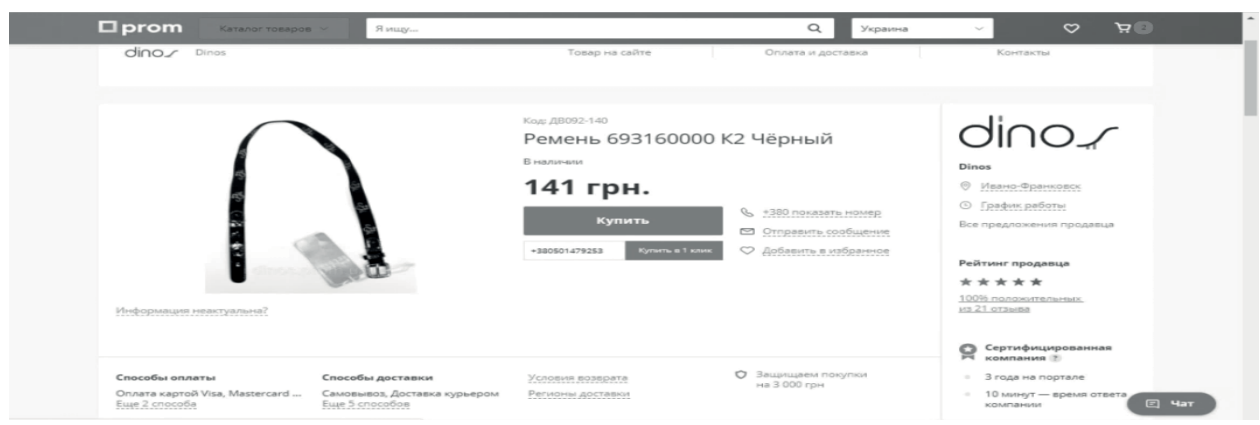

Текст В

\begin{tabular}{|c|c|}
\hline $\begin{array}{l}\text { mam } \\
\text { Активний } \\
\text { учасник }\end{array}$ & $\begin{array}{l}\text { Еезпілотні трамваї } \\
\text { Через пару десятків років весь транспорт перейде на електрику. } \\
\text { Відімруть звичні тролейбуси. Їх місце займуть безпілотні трамваї. В } \\
\text { Китаї запустили перший безпілотний трамвай. http://www.epravda.com.ua/ } \\
\text { news/2017/08/2/627680/ }\end{array}$ \\
\hline & \# \\
\hline$\frac{\text { yarko3 }}{\text { Banned }}$ & $\begin{array}{l}\text { Відповідь: Безпілотні трамваї } \\
\text { Можливо не весь на електрику. Частина машин може залишитися на } \\
\text { метані/пропані, який будуть синтезувати } 3 \text { атмосферної вуглекислоти і } \\
\text { води. }\end{array}$ \\
\hline & $\# 3$ \\
\hline $\begin{array}{l}\text { mam } \\
\text { Активний } \\
\text { учасник }\end{array}$ & $\begin{array}{l}\text { E Відповідь: Безпілотні трамваї } \\
\text { Скоріше на торфі ) Хто побагаче буде на Теслах ганяти... }\end{array}$ \\
\hline
\end{tabular}


Вплив досвіду користування інтернетом на особливості...

\section{Текст $\Gamma$}

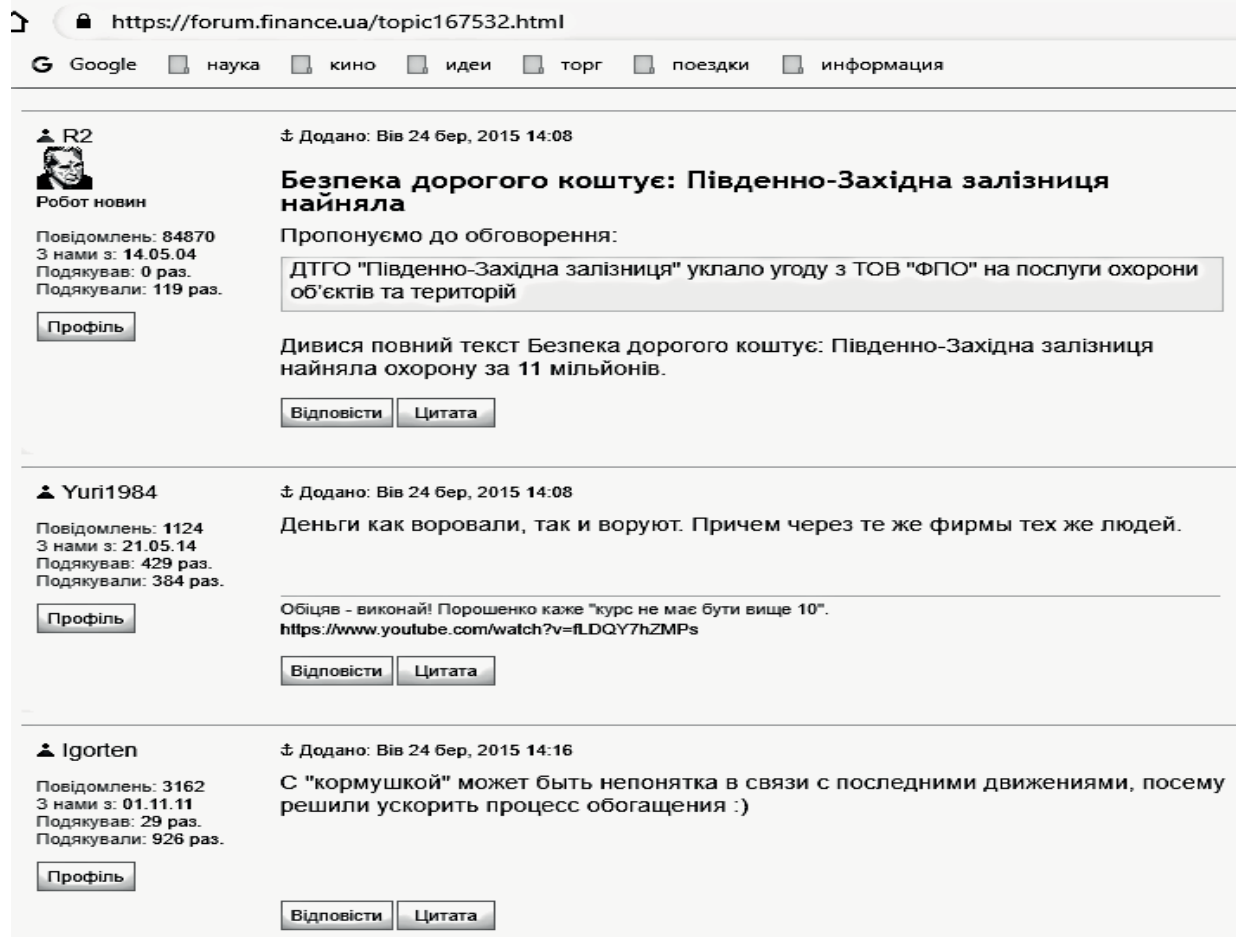

\section{Текст Д}

\section{Довжина тротуару ідеальна для моїх пробіжок}

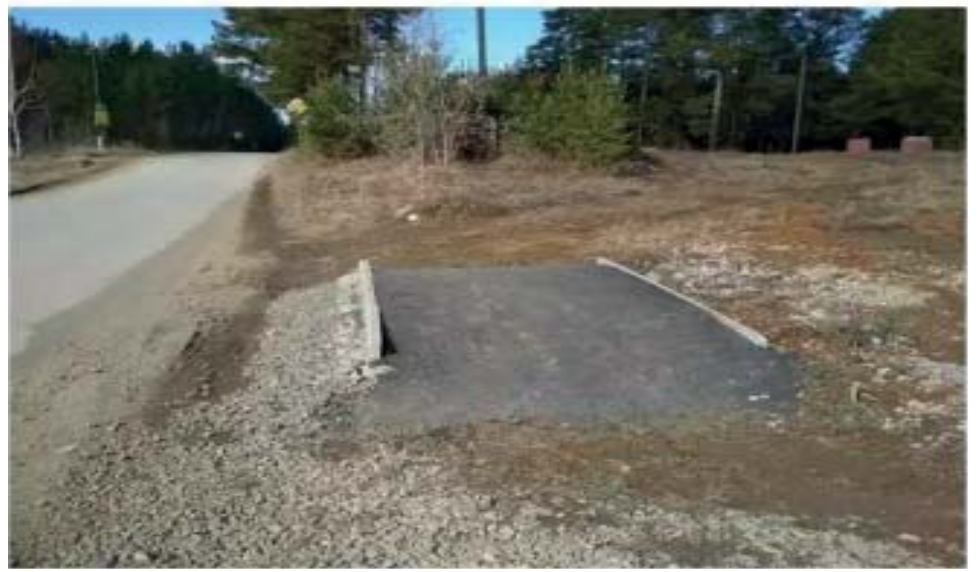


Impact of the Internet Using Experience on the Peculiarities...

Текст E

Пост-бумеранг: як одна публікачія може зробити диво?

Жив собі невеличкий сайт про київський мікрорайон Відрадний. Збирав на день по 50-70 відвідувачів, які без особливого ентузіазму читали публікації про новини з життя у чій місцевості. Та одного разу я (адмін сайту) вирішила поєднати в одному пості пораду писати про те, що цікаво самому автору, з простим маркетинговим ходом. Лінк за лінк - за таким принципом почала діяти розкрутка нової публікащії.

\section{Текст $\mathbf{E}$}

НГ: «Смерчі» за східною иіною 17 серпня 2012, 09:34

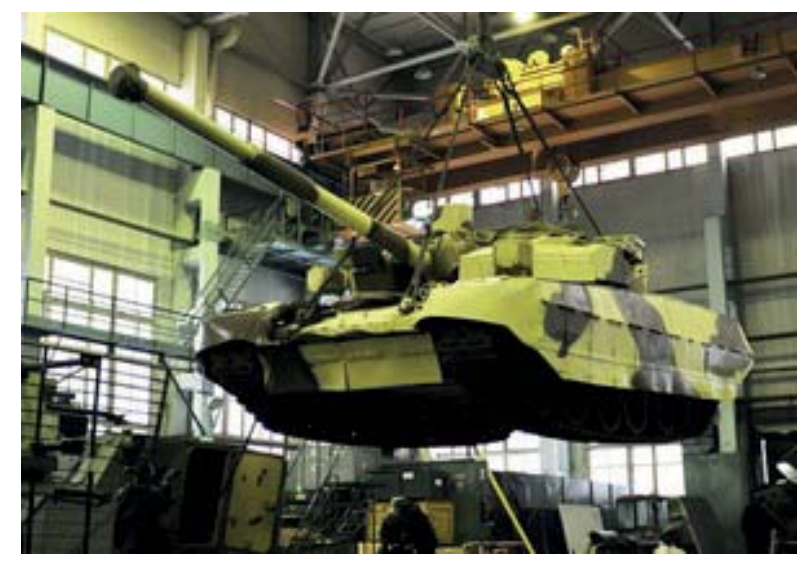

Фото: $A P$

Україна все ж могла постачати зброю Вірменії, вважають y Баку. Офіційні особи Украйни спростували інформацію про прихований продаж зброї Вірменії через Молдову, про щзо днями повідомили українські 3МI. Проте експертне співтовариство Азербайджану дотримується думки, щзо спроба вчинення подібної угоди могла мати місие, - пишуть Сохбет Мамедов і Світлана Гамова в російській Независимой газете.

\section{Текст Ж}

Суханова Вика. Получили соковыюималку, уже успели протестировать и спешу написать отзыв. Очень много читала о пользе сока именно со шнековой соковыжималки. Поэтому выбрала эту! Делали сок из морковки, яблок, сельдерея, тапинамбура, 
Вплив досвіду користування інтернетом на особливості...

апельсин, грейфрут. Все очень хорошо передаваться. Жмых достаточно сухой (я с него ещё иногда что-то делаю), по сравнению с иентробежной соковыжималку. Очень рекомендую.

Достоинства: Сок потрясающе вкусный

Недостатки: нет

\section{Текст 3}

Іхали козаки чоловік 120... Продовжіть далі... (33 коментаря на 5.10.18 Учасники 185 883).

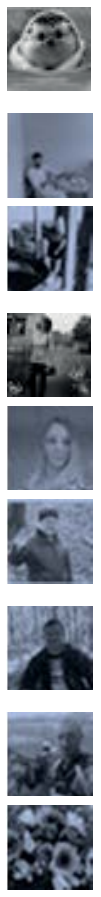

Кротевич Василь Станіславович Ой підманули, ой підманули Галю)

Yura Nechiporyk Підманули Галю стаття 117

Галина Небор Таак, ану швидко розясніть, шо то за статті maкi)))

Oksana Baranyuk Та най їууть далі)))

Люда Рахимова Підманули Галю стаття 117

Володимир Володимир Всім дівчатам у селі тепер не до танців

Олексій Кузик Чого тільки Галя фігурує в циих дурнуватих uзитатах? Тим більше написаних абсолютно безграмотно?

Olek Hal верталися до дому бо в галі прищ на срачі)

Наташа Брюханова $і$ доӥхали на війну, і війну прикінчили, $i$ вернулись до своїх Галь. а юристам пора шукати номер статті «про укладення шлюбу»

Леонид Сидоренко і стали шоб на захарченка посрать))

Іванна Козак Випили горілки, літрів 11н

\section{Текст I}

Петро Порошенко був (була) в ефрipi. 20 вересня о 10:35

Перша реакиія світу на окупацію Криму виявилася напрочуд млявою та беззубою. Та навіть тепер - після тисяч спричинених Росією жертв на Донбасі, після МН17, після Сирії, після Солсбері - 
на Заході чимало охочих зазирнути Путіну в душу, чи ще не знаю куди. Глибоко помиляється той, хто думає, ніби російська агресія забезпечуе нам автоматичну підтримку на Заході. За підтримку треба боротися щзодня.

За чотири з половиною роки нам вдалося не просто створити $i$ зберегти потужну трансатлантичну коаліцію на підтримку України, а й значно розтирити $і$ зміцнити ї̈.

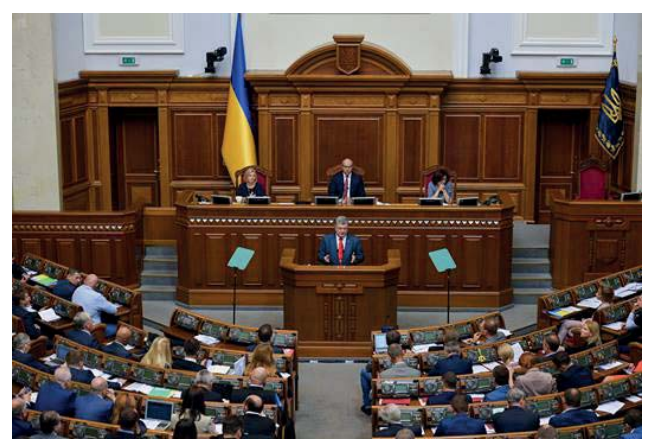

\author{
1,6 тис. коментарів \\ 818 Shares \\ 81 тис. Переглядів
}

27 Vlad Svidlo 15:22 Порох умница, если б ещче «простыле люди» чаще мозг включали чтоб понять что он делает для страны

6. Larissa Ziaziun 9:49 Пора вже обирати нормальний Парламент! A тих, хто виходить з залу під час виступу Президента, в зал більше не впускати, а гнати звідтам! Пора вже зняти з тих негідників недоторканість!

До кожного з цих текстів було запропоновано низку тотожних завдань:

1. Про щуо ичей текст? Поясніть.

2. Яким постає об'єкт обговорення?

3. Підкресліть незрозумілі слова, напишіть, якими словами Ви б їх замінили?

4. Поставте по 1-3 питання до изього тексту.

5. Оиініть ступінь складності розуміння (від 1 до 5: 1 зовсім незрозуміло - 5 - зрозуміло без варіантів), підкресліть слова, щуо ускладнюють розуміння. $1 \quad 2 \quad 3 \quad 4 \quad 5$

6. Оиініть рівень об'єктивності передачі інформації (О-об'єктивно, СК - суб'єктивно критично, СС - суб'єктивно схвально). О СК СС 
Вплив досвіду користування інтернетом на особливості...

7. Напишіть відгук до изього тексту.

8. Чи допомагає малюнок у розумінні изього тексту?

\section{Значення досвіду користування інтернетом на етапі рецепції}

На етапі рецепції формується загальне уявлення щодо тексту, його розміру, граматичної правильності, виникає нечіткий прогноз того, про що йтиметься у тексті, на основі чого виникає зацікавленість. Критеріями розуміння на цьому етапі було визначено:

1. Активність рецепції текстів інтернету (АРTI), яка позначається зосередженістю чи ігноруванням при виборі текстів для розуміння, а ії показником є кількість обраних текстів.

2. Точність очікувань реципієнта (ТОР), що відображає читацький прогноз відносно змісту тексту та верифікується показником співпадіння домінант у вторинних текстах - реакціях на фрагмент тексту та повний первинний текст.

Таблиця 2. Активність рецепції текстів інтернету залежно від досвіду користування та інтернет-активності

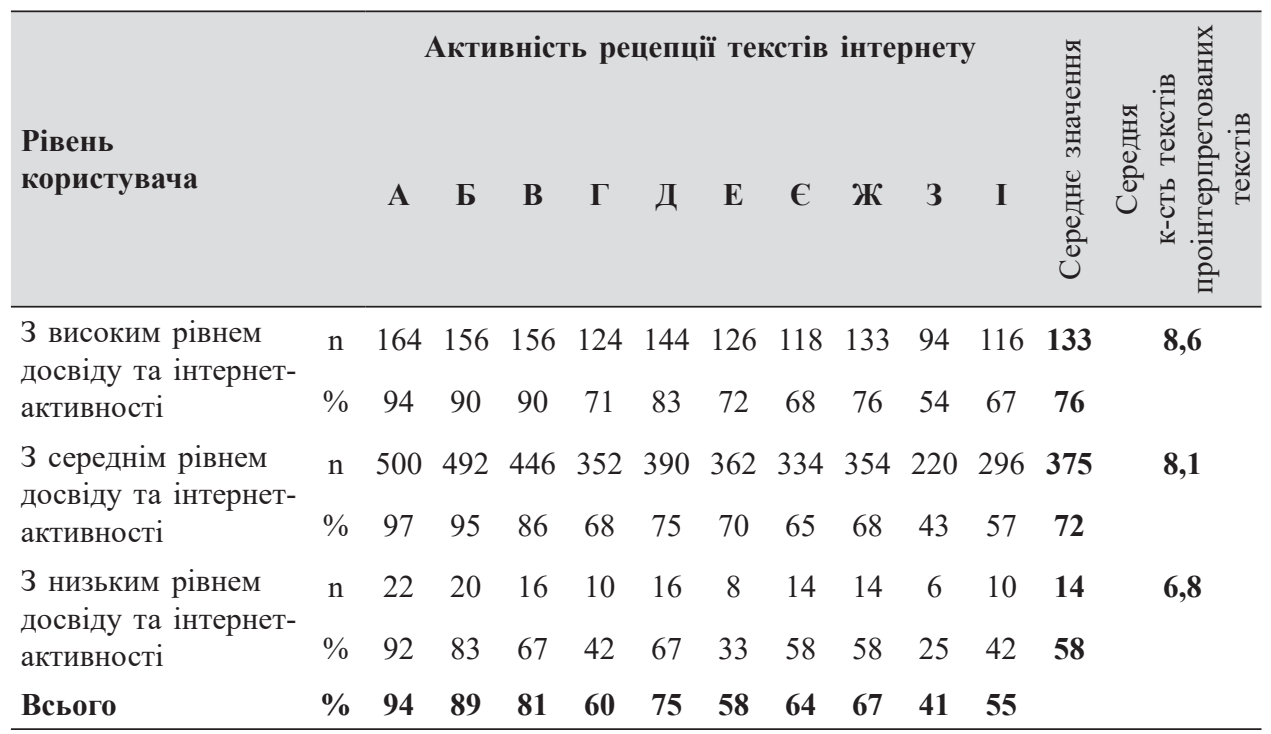

Загалом, рівень досвіду прямо корелює з рівнем активності рецепції текстів інтернету, більш досвідчені респонденти 
проглядають та інтерпретують більше текстів, така ж тенденція і по інших групах. Найбільше уваги привертають рекламні тексти побутової тематики, найменш цікаві - політичні та економічні тексти різних жанрів. Більше половини постійних користувачів прочитали усі запропоновані тексти (розмах варіації 54-94\%), їх увага $\epsilon$ досить стійка, вони відносно легко переключаються 3 одного типу тексту на інший. Майже половина типових користувачів виявила таку ж поведінку (розмах варіації 43-97\%), проте тут вже значно помітнішим є рівень втоми. Лише чверть випадкових користувачів проглянули усі тексти (розмах варіації 25-92\%), активність їх рецепції сильно коливається залежно від типу та складності тексту, їх сприйняття більш вибіркове, в них ще не сформована звичка читати усе підряд, що пропонується в інтернеті.

Динаміку активності рецепції респондентів кожної групи відтворено на рис. 1.

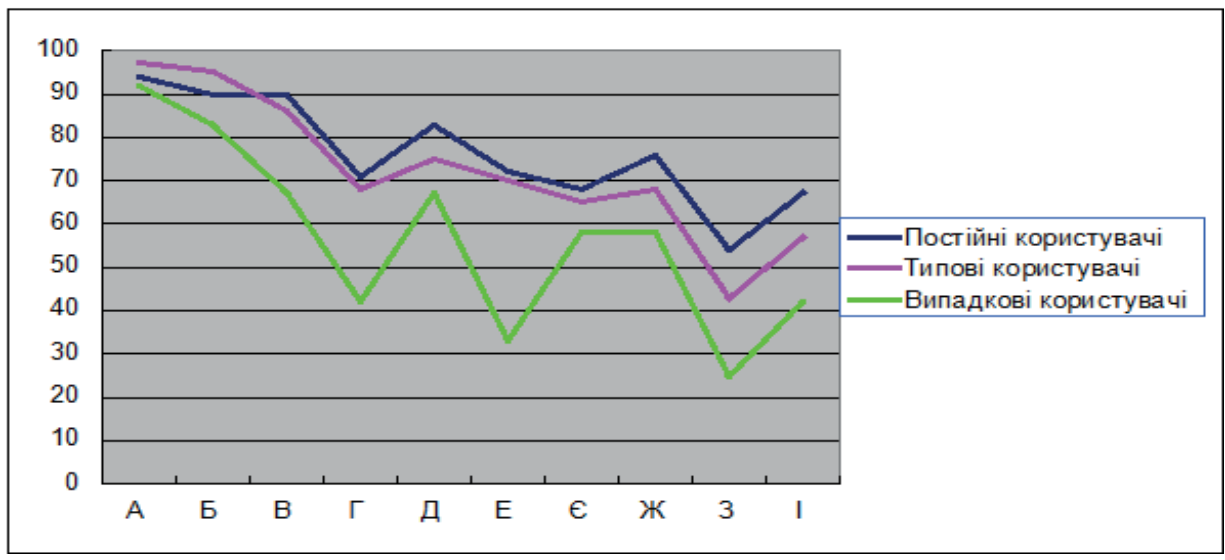

Рис. 1. Динаміка активності рецепиії респондентів кожної групи

Оцінки за критерієм «Точність очікувань реципієнтів» представлено в таблиці (Табл. 3).

Емпіричні дані свідчать, що досвід користування та рівень інтернет-активності прямо корелюють 3 точністю очікувань, випадкові користувачі значно гірше прогнозують зміст інтернеттексту за назвою, і ще гірші їх прогнози за малюнком, лише 13 5 респондентів вдалося зробити вірні прогнози. На відміну від цього різниці у точності прогнозів користувачів 3 високим та середнім рівнем досвіду та інтернет-активності майже не має $(2,0 \%$ 
Вплив досвіду користування інтернетом на особливості...

$\epsilon$ статистично не значимою різницею на такій вибірці). Проте навіть досвідчені користувачі інтернету у більше ніж половині випадків роблять хибні прогнози $(60,0 \%)$ за назвою та ілюстрацією, ймовірно, це пояснюється складністю та девіантністю текстів інтернету. Досвід допомагає у прогнозуванні змісту тексту лише на $15,0 \%$, можливо для покращення точності очікувань потрібне спеціальне навчання у межах медіа освітніх програм.

Таблиця 3. Точність очікувань реципієнтів залежно від досвіду користування та інтернет-активності

\begin{tabular}{lcccc}
\hline Рівень користувача & Показник & $\begin{array}{c}\text { Завдання 1 } \\
\text { (6 вербальних } \\
\text { текстів) }\end{array}$ & $\begin{array}{c}\text { Завдання 2 } \\
\text { (3 мультимедійні } \\
\text { тексти) }\end{array}$ & $\begin{array}{c}\text { Середнє } \\
\text { значення }\end{array}$ \\
\hline 3 високим рівнем досвіду & текстів & 2,6 & 1,1 & \\
та інтернет-активності & $\%$ & $43 \%$ & $37 \%$ & $\mathbf{4 0 \%}$ \\
3 середнім рівнем досвіду & текстів & 2,6 & 1,2 & \\
та інтернет-активності & $\%$ & $43 \%$ & $40 \%$ & $\mathbf{4 2 \%}$ \\
3 низьким рівнем досвіду & текстів & 2,0 & 0,6 & \\
та інтернет-активності & $\%$ & $33 \%$ & $20 \%$ & $\mathbf{2 7 \%}$ \\
\hline
\end{tabular}

Загалом, рівень досвіду та інтернет-активності впливає на процес розуміння вже на етапі рецепції, прямо корелюючи як 3 рівнем активності рецепції, так і щодо точності очікувань реципієнтів. Ступінь цього впливу коливається у межах 15,0 18,0\%. Отже, можна припустити, що адекватність рецепції текстів інтернету залежить також і від інших чинників.

\section{Значимість досвіду користування інтернетом на етапі інтерпретації}

На етапі інтерпретації відбувається раціональне тлумачення смислового складу текстів інтернету за участю процесів мислення, пам'яті, мовлення, зокрема операцій аналізу та синтезу, порівняння, абстрагування i узагальнення, пригадування, смислоформування, семантичного синтаксування, експлікації тощо. Критерієм ефективності розуміння на цьому етапі є:

1. Адекватність інтерпретації текстів інтернету (AITI), тобто виділення домінант 3 первинного тексту та їх відповідна репрезентація у вторинному. 
Impact of the Internet Using Experience on the Peculiarities...

2. Повнота інтерпретації текстів інтернету (ПІТІ), тобто наявність у вторинному тексті всіх відповідників до смислових домінант з первинного тексту.

Емпіричні результати за цими критеріями узагальнено у таблиці 4.

Таблиця 4. Адекватність та повнота інтерпретації текстів інтернету залежно від досвіду користування та інтернет-активності

\begin{tabular}{|c|c|c|c|c|c|c|c|c|c|c|c|c|}
\hline \multirow{2}{*}{$\begin{array}{l}\text { Рівень } \\
\text { користувача }\end{array}$} & \multirow[b]{2}{*}{ Показник } & \multicolumn{10}{|c|}{ Текст інтернету } & \multirow{2}{*}{ 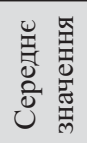 } \\
\hline & & $\mathbf{A}$ & Б & B & $\Gamma$ & Д & $\mathbf{E}$ & $\mathbf{C}$ & ж & 3 & $\mathbf{I}$ & \\
\hline \multirow{2}{*}{$\begin{array}{l}3 \text { високим рівнем } \\
\text { досвіду та } \\
\text { інтернет-активності }\end{array}$} & $\begin{array}{c}\text { AITI } \\
\text { домінант }\end{array}$ & 1,7 & 1,6 & 2,0 & 1,4 & 1,3 & 1,0 & 1,8 & 1,5 & 0,9 & 1,2 & 14,4 \\
\hline & ПІТІ \% & 34 & 40 & 50 & 20 & 33 & 16 & 23 & 30 & 18 & 15 & $27,9 \%$ \\
\hline \multirow{2}{*}{$\begin{array}{l}3 \text { середнім } \\
\text { рівнем досвіду та } \\
\text { інтернет-активності }\end{array}$} & $\begin{array}{c}\text { AITI } \\
\text { домінант }\end{array}$ & 1,9 & 1,6 & 1,8 & 1,3 & 1,1 & 1,2 & 1,6 & 1,2 & 0,6 & 1,0 & 13,3 \\
\hline & ПІТІ \% & 38 & 40 & 45 & 19 & 28 & 20 & 20 & 24 & 12 & 13 & $25,9 \%$ \\
\hline \multirow{2}{*}{$\begin{array}{l}3 \text { низьким рівнем } \\
\text { досвіду та } \\
\text { інтернет-активності }\end{array}$} & $\begin{array}{c}\text { AITI } \\
\text { домінант }\end{array}$ & 1,4 & 1,3 & 1,2 & 0,8 & 0,6 & 0,4 & 2,2 & 1,2 & 0,3 & 0,5 & 9,9 \\
\hline & ПІТІ \% & 28 & 33 & 30 & 11 & 15 & 7 & 28 & 24 & 6 & 6 & $18,8 \%$ \\
\hline $\begin{array}{l}\text { Загальна } \\
\text { кількість } \\
\text { домінант }\end{array}$ & домінант & 5 & 4 & 4 & 7 & $\begin{array}{l}4 \mathrm{~T} \\
2 \mathrm{M}\end{array}$ & 6 & $\begin{array}{l}8 \mathrm{~T} \\
1 \mathrm{M}\end{array}$ & 5 & 5 & $\begin{array}{l}8 \mathrm{~T} \\
1 \mathrm{M}\end{array}$ & 6 \\
\hline
\end{tabular}

Адекватність інтерпретації текстів інтернету знаходиться у прямій залежності від досвіду користування та інтернет-активності: чим більше часу респондент проводить в мережі, тим точніша його інтерпретація інтернет-текстів. Проте тексти інтернету є складними для раціонального тлумачення, досвідчені користувачі змогли вірно інтерпретувати лише чверть домінант, тоді як випадкові лише шосту частину. Аналогічно позначається вплив чинника досвіду і на повноті інтерпретації текстів інтернету. Постійні i типові користувачі, як правило, більш повно інтерпретують тексти інтернету, ніж випадкові користувачі, але мова йде, у кращому випадку, про трактування лише чверті ключових слів 3 поданих текстів. Найлегшою для досвідчених користувачів виявилася інтерпретація рекламних оголошень та технічних чатів, найскладнішою політичних постів. Випадкові користувачі, ймовірно, найчастіше читають в інтернеті рекламні оголошення, 
Вплив досвіду користування інтернетом на особливості...

технічні чати та новини, ці тексти вони інтерпретували найкраще, найгірше їм вдалося тлумачити пости різної тематики (технічні, політичні, жартівливі), в середньому вони змогли інтерпретувати лише двадцяту частину їх змісту, що певно, пояснюється низьким рівнем інтернет-креативності цієї групи, вони не пишуть пости і вочевидь рідко їх читають.

Динаміку адекватності та повноти інтерпретації текстів інтернету відтворено на рис. 2.

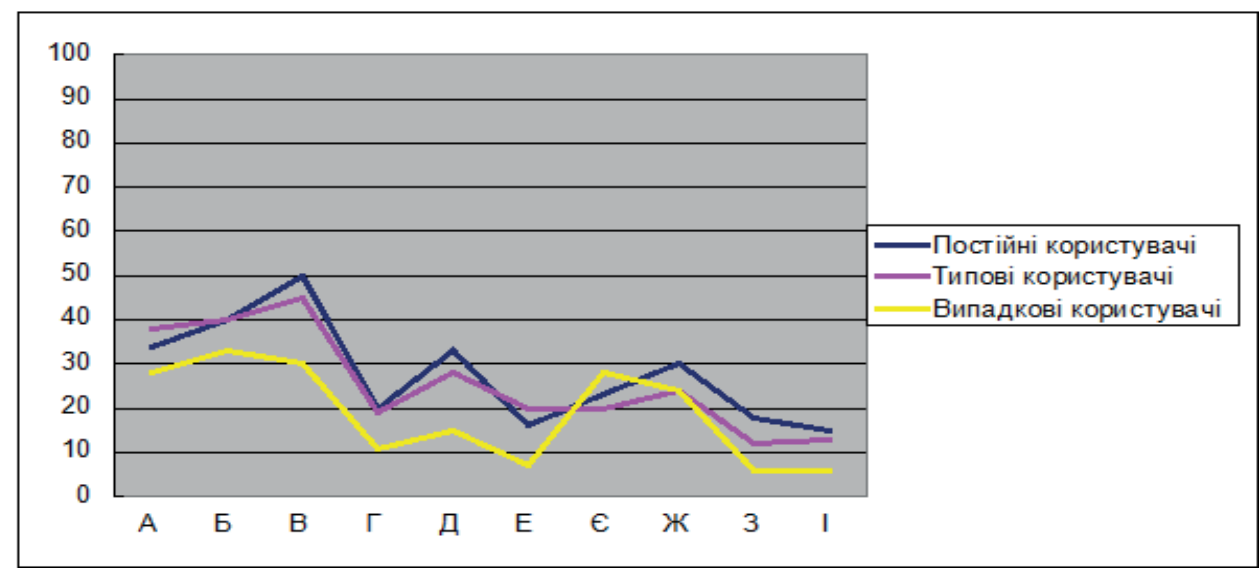

Рис. 2. Динаміка адекватності та повноти інтерпретаиії текстів інтернету

Загалом, рівень досвіду та інтернет-активності впливає на процес розуміння на етапі інтерпретації, прямо корелюючи як 3 рівнем адекватності інтерпретації текстів інтернету, так і щодо повноти їх тлумачення. Ступінь цього впливу коливається у межах 9,0-10,0\%. Важливо, що чинник досвіду та інтернет-активності виявився майже вдвічі більш значимим на етапі рецепції текстів інтернету (15,0-18,0\%), ніж їх інтерпретації $(9,0-10,0 \%)$.

\section{Значення досвіду користування інтернетом на етапі емоційної ідентифікації}

На етапі емоційної ідентифікації відбувається доповнення вторинного тексту ймовірними емоційними конотаціями, усвідомлення авторської оцінки та формування власної, а також їх співвіднесення. Критеріями розуміння на цьому етапі визначено такі: 
Impact of the Internet Using Experience on the Peculiarities...

1. Оцінка зрозумілості текстів інтернету (ОЗТІ), яку респонденти визначають за п'ятибальною шкалою, керуючись власними уявленнями про складність розуміння тексту інтернету.

2. Узгодженість емоційного ставлення до текстів інтернету (УЕСТI), що виражається через відповідність конотацій у первинному та вторинному текстах, а іiі показником $\epsilon$ відсоток співпавших конотацій вторинного тексту у відповідях на питання № 2, 6 та 7 .

Емпіричні результати за критерієм оцінки зрозумілості текстів інтернету подано у таблиці (Табл. 5).

Для визначення адекватності оцінки можемо встановити співвідношення оцінки складності розуміння з показником повноти інтерпретації текстів інтернету, показником адекватності оцінки у такому разі буде коефіцієнт їх співвідношення. Для зручності співставлення переведемо ОЗТІ з п'ятибальної шкали, пропонованої досліджуваним, у стобальну.

Таблиця 5. Емпіричні результати за критерієм «Оцінка зрозумілості текстів інтернету»

\begin{tabular}{|c|c|c|c|c|c|c|c|c|c|c|c|c|c|}
\hline \multirow{2}{*}{$\begin{array}{l}\text { Рівень } \\
\text { користувача }\end{array}$} & \multirow{2}{*}{ 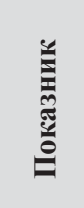 } & \multirow[b]{2}{*}{$\mathbf{A}$} & \multirow[b]{2}{*}{ Б } & \multirow[b]{2}{*}{ B } & \multicolumn{4}{|c|}{ Текст інтернету } & \multirow[b]{2}{*}{ ж } & \multirow[b]{2}{*}{3} & \multirow[b]{2}{*}{$\mathbf{I}$} & \multirow{2}{*}{ 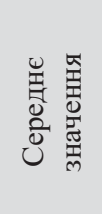 } & \multirow{2}{*}{ 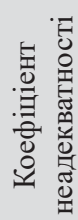 } \\
\hline & & & & & $\Gamma$ & Д & $\mathbf{E}$ & $\mathbf{C}$ & & & & & \\
\hline \multirow{3}{*}{$\begin{array}{l}3 \text { високим } \\
\text { рівнем досвіду } \\
\text { та інтернет- } \\
\text { активності }\end{array}$} & O3TI & 4,0 & 4,0 & 4,1 & 3,9 & 3,9 & 3,7 & 3,9 & 3,8 & 3,7 & 3,8 & 3,9 & \multirow{3}{*}{50,1} \\
\hline & бали & 80 & 80 & 82 & 78 & 78 & 74 & 78 & 76 & 74 & 76 & 78 & \\
\hline & $\underset{\%}{\Pi \text { ПІТІ }}$ & 34 & 40 & 50 & 20 & 33 & 16 & 23 & 30 & 18 & 15 & $27,9 \%$ & \\
\hline \multirow{3}{*}{$\begin{array}{l}3 \text { середнім } \\
\text { рівнем досвіду } \\
\text { та інтернет- } \\
\text { активності }\end{array}$} & O3TI & 3,7 & 3,7 & 3,9 & 3,7 & 3,7 & 3,3 & 3,2 & 3,7 & 3,0 & 3,4 & 3,5 & \multirow{3}{*}{44,1} \\
\hline & бали & 74 & 74 & 78 & 74 & 74 & 66 & 64 & 74 & 60 & 68 & 70 & \\
\hline & $\underset{\%}{\Pi \text { ПITI }}$ & 38 & 40 & 45 & 19 & 28 & 20 & 20 & 24 & 12 & 13 & $25,9 \%$ & \\
\hline \multirow{3}{*}{$\begin{array}{l}3 \text { низьким } \\
\text { рівнем досвіду } \\
\text { та інтернет- } \\
\text { активності }\end{array}$} & O3TI & 3,1 & 3,0 & 3,7 & 3,0 & 5,0 & 4,5 & 4,8 & 4,5 & 3,3 & 4,0 & 3,9 & \multirow{3}{*}{59,2} \\
\hline & бали & 62 & 60 & 74 & 60 & 100 & 90 & 96 & 90 & 66 & 80 & 78 & \\
\hline & $\begin{array}{c}\text { ПІТІ } \\
\%\end{array}$ & 28 & 33 & 30 & 11 & 15 & 7 & 28 & 24 & 6 & 6 & $18,8 \%$ & \\
\hline
\end{tabular}

Рівень досвіду та інтернет-активності, орієнтуючись на середнє значення, представлене в таблиці, не впливає на оцінку зрозумілості текстів інтернету. Проте постійні користувачі 
оцінюють текст інтернету більш однорідно (розмах варіації: 3,74,1), ніж випадкові користувачі (розмах варіації: 3,0-5,0). Типовим користувачам тексти інтернету здаються складнішими, ніж новачкам чи професіоналам, проте їх оцінки також досить неоднорідні (розмах варіації: 3,0-3,9). Крайні оцінки переважають лише у групі випадкових користувачів, які схильні оцінювати тексти інтернету досить оптимістично (5 балів - цілком зрозуміло), спостерігаємо ефект впевненості новачків. 3 таблиці видно, що респонденти усіх груп недооцінюють складність усіх пропонованих текстів інтернету, незалежно від жанру, тематики та особливостей тексту. У досліджених склався стійкий, але невиправданий стереотип щодо простоти текстів інтернету. Найбільш неадекватні оцінки складності в усіх групах користувачів отримали тексти постів різної тематики, які оцінюються опитуваними як одні 3 найпростіших, а між тим виявляються одними 3 найскладніших для інтерпретації, ïx коефіцієнт неадекватності оцінки по різних групах i текстах складає від 46 до 83 балів. Загалом усі оцінки респондентів сильно відрізняються від їх фактичних можливостей інтерпретації цих текстів, це наводить на думку, що оцінка складності текстів інтернету складне завдання для непідготовленого читача, ця навичка не формується автоматично 3 накопиченням досвіду, а потребує спеціального навчання. Коефіцієнт різниці свідчить, що з досвідом ця навичка не покращується.

Важливою операцією розуміння на етапі емоційної ідентифікації $\epsilon$ узгодження емоційного ставлення до тексту, це ставлення формується несвідомо та автоматично та має важливе значення в процесі усвідомлення результату розуміння. Емпіричні результати за критерієм узгодженості емоційного ставлення до текстів інтернету зазначені у таблиці (Табл. 6).

Аналіз результатів, представлених у таблиці, дає підстави стверджувати, що більшість користувачів незалежно від рівня досвідченості ставляться до текстів інтернету переважно або критично, або схвально. Нейтральні оцінки $є$ малочисельними. Досвідченим користувачам простіше вдається оцінювати власне ставлення до тексту (71,0\% постійних і 67,0\% типових користувачів зробили це), їх оцінки є більш узгодженими, на відміну від випадкових користувачів, у групі яких не зафіксовано жодного узгодженого ставлення за чотирма 3 десяти представлених 
Impact of the Internet Using Experience on the Peculiarities...

Таблиця 6. Оцінка узгодженості емоційного ставлення до текстів інтернету залежно від досвіду користування та інтернет-активності

\begin{tabular}{|c|c|c|c|c|c|c|c|c|c|c|c|c|}
\hline \multirow{2}{*}{$\begin{array}{l}\text { Рівень } \\
\text { корис- } \\
\text { тувача }\end{array}$} & \multirow{2}{*}{$\begin{array}{l}\text { Емоційне } \\
\text { ставлення } \\
\text { (з них } \\
\text { узгоджених) }\end{array}$} & \multicolumn{10}{|c|}{ Текст інтернету } & \multirow{2}{*}{$\begin{array}{c}\text { Мода } \\
\text { (по } \\
\text { текстах) }\end{array}$} \\
\hline & & $\mathbf{A}$ & $\mathbf{6}$ & B & $\Gamma$ & Д & $\mathbf{E}$ & $\mathbf{C}$ & Ж & 3 & I & \\
\hline \multirow{9}{*}{$\begin{array}{l}3 \text { високим } \\
\text { рівнем } \\
\text { досвіду та } \\
\text { інтернет- } \\
\text { активності }\end{array}$} & нейтральне & 48 & 74 & 42 & 43 & 48 & 34 & 36 & 48 & 46 & 32 & \\
\hline & (узгоджене) & (4) & (12) & (2) & & (2) & (3) & & & & (2) & \\
\hline & критичне & 56 & 28 & 50 & 62 & 30 & 46 & 53 & 22 & 44 & 50 & $\mathbf{A}, \mathbf{B}, \Gamma$ \\
\hline & (узгоджене) & (36) & $(10)$ & $(16)$ & $(18)$ & (4) & $(10)$ & $(23)$ & & (18) & $(16)$ & $\mathbf{C}, \mathbf{3}, \mathbf{I}$ \\
\hline & схвальне & 44 & 34 & 42 & 26 & 40 & 34 & 24 & 42 & 31 & 32 & Б, Д, E, \\
\hline & (узгоджене) & (16) & (14) & (14) & (2) & (9) & (18) & (3) & (24) & $(16)$ & (7) & \\
\hline & $\begin{array}{l}\text { Загальна } \\
\text { кількість } \\
\text { ставлень }\end{array}$ & 148 & 136 & 134 & 131 & 118 & 114 & 113 & 112 & 121 & 114 & $\begin{array}{c}1241 \\
71 \% \\
\text { опитаних }\end{array}$ \\
\hline & (узгоджених) & 56 & 36 & 32 & 20 & 15 & 31 & 26 & 24 & 34 & 25 & 23.8 \\
\hline & $\%$ & $38 \%$ & $27 \%$ & $24 \%$ & $15 \%$ & $13 \%$ & $27 \%$ & $23 \%$ & $21 \%$ & $28 \%$ & $22 \%$ & \\
\hline \multirow{8}{*}{$\begin{array}{l}3 \text { середнім } \\
\text { рівнем } \\
\text { досвіду та } \\
\text { інтернет- } \\
\text { активності }\end{array}$} & нейтральне & 164 & 204 & 144 & 104 & 140 & 114 & 112 & 101 & 90 & 90 & \\
\hline & (узгоджене) & (2) & (6) & (10) & (3) & (4) & (4) & (2) & (2) & & (4) & \\
\hline & критичне & 152 & 98 & 128 & 182 & 106 & 88 & 134 & 72 & 138 & 110 & $\mathbf{A}, \boldsymbol{\Gamma}, \mathbf{C}$ \\
\hline & (узгоджене) & (70) & (26) & $(20)$ & (54) & (28) & (18) & $(40)$ & (8) & (56) & $(26)$ & 3, I \\
\hline & схвальне & 112 & 94 & 132 & 76 & 96 & 118 & 58 & 130 & 82 & 74 & Б, В, Д, \\
\hline & (узгоджене) & (34) & (34) & (34) & (6) & (33) & $(28)$ & (14) & (39) & (20) & (8) & \\
\hline & $\begin{array}{l}\text { Загальна } \\
\text { кількість } \\
\text { ставлень }\end{array}$ & 428 & 396 & 404 & 362 & 342 & 320 & 304 & 303 & 310 & 274 & $\begin{array}{c}3443 \\
67 \% \\
\text { опитаних }\end{array}$ \\
\hline & $\begin{array}{l}\text { (узгоджених) } \\
\text { \% }\end{array}$ & $\begin{array}{r}106 \\
25 \%\end{array}$ & $\begin{array}{c}66 \\
17 \%\end{array}$ & $\begin{array}{c}64 \\
16 \%\end{array}$ & $\begin{array}{c}63 \\
17 \%\end{array}$ & $\begin{array}{c}65 \\
19 \%\end{array}$ & $\begin{array}{c}50 \\
16 \%\end{array}$ & $\begin{array}{c}56 \\
18 \%\end{array}$ & $\begin{array}{c}49 \\
16 \%\end{array}$ & $\begin{array}{c}76 \\
25 \%\end{array}$ & $\begin{array}{c}38 \\
14 \%\end{array}$ & $18,4 \%$ \\
\hline \multirow{5}{*}{$\begin{array}{l}3 \text { низьким } \\
\text { рівнем } \\
\text { досвіду та } \\
\text { інтернет- } \\
\text { активності }\end{array}$} & $\begin{array}{l}\text { нейтральне } \\
\text { (узгоджене) }\end{array}$ & 2 & 4 & & & & & & 2 & 2 & & \\
\hline & $\begin{array}{l}\text { критичне } \\
\text { (узгоджене) }\end{array}$ & $\begin{array}{l}12 \\
(6)\end{array}$ & 6 & $\begin{array}{l}10 \\
(2)\end{array}$ & 4 & 4 & & 4 & 2 & $\begin{array}{c}4 \\
(4)\end{array}$ & $\begin{array}{c}6 \\
(4)\end{array}$ & $\mathbf{A}, \mathbf{B}, \mathbf{3}, \mathbf{I}$ \\
\hline & $\begin{array}{l}\text { схвальне } \\
\text { (узгоджене) }\end{array}$ & 2 & $\begin{array}{c}2 \\
(2)\end{array}$ & 4 & 2 & 4 & 2 & 4 & $\begin{array}{c}2 \\
(2)\end{array}$ & & 2 & Б, Ж \\
\hline & $\begin{array}{l}\text { Загальна } \\
\text { кількість } \\
\text { ставлень }\end{array}$ & 16 & 12 & 14 & 6 & 8 & 2 & 8 & 6 & 6 & 8 & $\begin{array}{c}86 \\
36 \% \\
\text { опитаних }\end{array}$ \\
\hline & $\begin{array}{l}\text { (узгоджених) } \\
\text { \% }\end{array}$ & $\begin{array}{c}6 \\
38 \%\end{array}$ & $\begin{array}{c}2 \\
17 \%\end{array}$ & $\begin{array}{c}2 \\
14 \%\end{array}$ & $\mathbf{0}$ & $\mathbf{0}$ & $\mathbf{0}$ & $\mathbf{0}$ & $\begin{array}{c}2 \\
33 \%\end{array}$ & $\begin{array}{c}4 \\
67 \%\end{array}$ & $\begin{array}{c}4 \\
50 \%\end{array}$ & $23,3 \%$ \\
\hline
\end{tabular}


у досліджені текстів, та й сформувати власне ставлення до текстів змогли лише третина респондентів цієї групи. Труднощі узгодження емоційного ставлення в групі користувачів 3 низьким рівнем досвіду та інтернет-активності викликали чотири тексти різних жанрів та тематичного спрямування, що, на нашу думку, свідчить про складнощі емоційного розуміння незалежно від типу тексту інтернету. Крім того постійні користувачі більш критичні в своєму ставленні, ніж інші групи. Узгодити власне критичне ставлення також легше вдається і випадковим користувачам. Критичну реакцію викликають стандартні рекламні банери та пости жартівливого (гумор в інтернеті є досить специфічним та іноді супроводжується бранною лексикою, що, як виявилося, не дуже подобається читачам) та політичного змісту. Переважно схвальні узгоджені оцінки отримали один з рекламних текстів та позитивний відгук, вочевидь саме ці типи текстів досліджувані вважають найбільш приємними. Також досвідченим користувачам подобаються меми та технічні пости, у той час, як випадковим користувачам важко визначити своє ставлення до цих специфічних інтернет-текстів.

Загалом, рівень досвіду та інтернет-активності суттєво не впливає на процес розуміння на етапі емоційної ідентифікації, хоча й були виявлені окремі тенденції по групах користувачів з різними рівнем досвіду, проте встановити чітких кореляцій не вдалося. Емоційне розуміння текстів інтернету виявилося досить складним як щодо оцінки зрозумілості цих текстів, так і щодо узгодженості емоційного ставлення. Низькі показники успішності емоційного розуміння не покращуються самостійно в процесі накопичення досвіду користування інтернетом.

\section{Висновки}

Рівень досвіду найбільш суттєво впливає на процес розуміння на етапі рецепції, скеровуючи активність користувачів та точність ïx очікувань. 3 накопиченням досвіду користування інтернетом покращуються стійкість та переключення уваги, збільшується рівень працездатності у віртуальному середовищі. Досвід сприяє точності прогнозування змісту текстів інтернету в середньому на 15,0\%. На етапі інтерпретації 3 накопиченням досвіду покращується майже 
Impact of the Internet Using Experience on the Peculiarities...

на 10,0\% адекватність та повнота тлумачення текстів інтернету. Однак тексти інтернету є складними для раціонального тлумачення, досвідчені користувачі змогли вірно інтерпретувати лише чверть домінант, тоді як випадкові - лише шосту частину. Ще менше значення має рівень досвіду та інтернет-активності на етапі емоційної ідентифікації, ані оцінка зрозумілості, ані узгодженість емоційного ставлення майже не залежать від досвіду користування інтернетом. 3 накопиченням досвіду користувачі оцінюють тексти інтернету більш однорідно, їм легше вдається усвідомлювати власне ставлення до текстів інтернету, воно стає більш узгодженим, проте, як i недосвідчені читачі, вони більше ніж у половині випадків недооцінюють складність текстів інтернету, так само схильні поділяти тексти на схвальні та критичні.

В подальших дослідженнях плануємо вивчити значимість інших суб’єктивних чинників у процесі розуміння текстів інтернету.

\section{Література}

Дейк, Т.А., \& Кинч, В. (1988). Стратегии понимания связного текста. Новое в зарубежной лингвистике, 23, 153-211.

Залевская, А.А. (1990). Слово в лексиконе человека. Психолингвистическое исследование. Воронеж.

Знаков, В.В. (2005). Психология понимания: Проблемы и перспективы. Москва: Изд-во «Институт психологии РАН.

Новиков, А.И. (1999). Смысл: семь дихотомических признаков. Теория и практика речевых исследований (с. 132-144). Москва: МГУ.

Чепелєва, Н.В. (1992). Психологія читання навчальної та наукової літератури в системі професійної підготовки студентів. (Автореф. дис. д-ра психол. наук). Київ: КДПІ ім. М.П. Драгоманова.

Щипицина, Л.Ю. (2011). Комплексная лингвистическая характеристика компьютерно-опосредованной коммуникации (на материале немецкого языка). (Автореф. дисс. д-ра филол. наук). Воронеж: Воронеж ун-т.

Akimoto, Y., Takahashi, H., Gunji, A., Kaneko, Y., Asano, M., Matsuo, J. ... Yoko, Y. (2017). Alpha band event-related desynchronization underlying social situational context processing during irony comprehension: A magnetoencephalography source localization study. Brain and Language, 175, 42-46. https://doi. org/10.1016/j.bandl.2017.09.002

Bitan, T., Kaftory, A., Meiri-Leib, A., Eviatar, Z., \& Peleg, O. (2017). Phonological ambiguity modulates resolution of semantic ambiguity during reading: An fMRI study of Hebrew. Neuropsychology, 31(7), 759-777. https://doi.org/10.1016/j. band1.2017.09.002

Bosco, F.M., \& Gabbatore, I. (2017). Theory of mind in recognizing and recovering communicative failures. Applied Psycholinguistics, 38(1), 57-88. https://doi. org/10.1017/S0142716416000047 
Вплив досвіду користування інтернетом на особливості...

Cummine, J., Cribben, I., Luu, C., Kim, E., Bakhtiari, R., Georgiou, G., \& Boliek, C.A. (2016). Understanding the role of speech production in reading: Evidence for a print-to-speech neural network using graphical analysis. Neuropsychology, 30(4), 385-397. https://doi.org/10.1037/neu0000236

De Freitas P.V., Peruzzi Ella Da Mota, M.M., \& Deacon, S.H. (2018). Morphological awareness, word reading, and reading comprehension in Portuguese. Applied Psycholinguistics, 39(3), 507-525. https://doi.org/10.1017/S0142716417000479

Foucart, A., Romero-Rivas, C., Gort, B.L., \& Costa, A. (2016). Discourse comprehension in L2: Making sense of what is not explicitly said. Brain and Language, 163, 32-41. https://doi.org/10.1016/j.bandl.2016.09.001

Giustolisi, B., Vergallito, A., Cecchetto, C., Varoli, E., \& Lauro, L.J. (2018). Anodal transcranial direct current stimulation over left inferior frontal gyrus enhances sentence comprehension. Brain and Language, 176, 36-41. https://doi. org/10.1016/j.bandl.2017.11.001

Graesser, A., Wiemer-Hastings, P., \& Wiemer-Hastings, K. (2001). Constructing Inferences and Relations during Text Comprehension. In Sanders, Schilperoord \& Spooren (Eds.), Text Representation: Linguistic and Psycholinguistic Aspects (pp. 21-26). Amsterdam / Philadelphia: Benjamins. https://doi.org/10.1075/ hcp.8.14gra

Hahne, C., Goldhammer, F., Kröhne, U., \& Naumann J. (2018). The role of reading skills in the evaluation of online information gathered from search engine environments. Computers in Human Behavior, 78, 223-234. https://doi. org/10.1016/j.chb.2017.10.004

Houghton, G. (2018). Action and perception in literacy: A common-code for spelling and reading. Psychological Review, 125(1), 83-116. https://doi.org/10.1037/ rev0000084

Hubers, F., Snijders, T., \& Hoop, H. (2016). How the brain processes violations of the grammatical norm: An fMRI study. Brain and Language, 163, 22-31. https://doi. org/10.1016/j.bandl.2016.08.006

Mason, L., Scrimin, S., Zaccoletti, S., Tornatora, M., \& Goetz, T. (2018). Webpage reading: Psychophysiological correlates of emotional arousal and regulation predict multiple-text comprehension. Computers in Human Behavior, 87, $317-$ 326. https://doi.org/10.1016/j.chb.2018.05.020

Ohadi, J., Brown, B., Trub, L., \& Rosenthal, L. (2018). I just text to say I love you: Partner similarity in texting and relationship satisfaction. Computers in Human Behavior, 78, 126-132. https://doi.org/10.1016/j.chb.2017.08.048

Sharon, E.M., \& Thompson-Schill, L. (2017). Tracking competition and cognitive control during language comprehension with multi-voxel pattern analysis. Brain and Language, 165, 21-32. https://doi.org/10.1016/j.bandl.2016.11.002

Van den Broek, P., Young, M., Tzeng, Y., \& Linderholm, T. (1999). The landscape model of reading. In H. van Oostendorp \& S.R. Goldman (Eds.), The Construction of Mental Representations During Reading (pp. 71-98). Mahwah, NJ: Erlbaum.

\section{References}

Deyk, T.A., \& Kinch, V. (1988). Strategii ponimaniya svyaznogo teksta [Strategies for understanding of coherent text]. Novoye $v$ zarubezhnoy lingvistike $-\mathrm{New}$ in Foreign Linguistics, 23, 153-211 [in Russian]. 
Impact of the Internet Using Experience on the Peculiarities...

Zalevskaya, A.A. (1990). Slovo $v$ leksikone cheloveka. Psikholingvisticheskoye issledovaniye [The word in the human lexicon. Psycholinguistic research]. Voronezh [in Russian].

Znakov, V.V. (2005). Psikhologiya ponimaniya: Problemy i perspektivy [Psychology of Understanding: Problems and Perspectives]. Moscow: Izd-vo «Institut psikhologii RAN» [in Russian].

Novikov, A.I. (1999). Smysl: sem dikhotomicheskikh priznakov [Sense: seven dichotomous signs]. Teoriya $i$ praktika rechevykh issledovaniy - Theory and Practice of Speech Research (pp. 132-144). Moscow: Moskovskiy gosudarstvennyy universitet [in Russian].

Chepelyeva, N.V. (1992). Psykholohiya chytannya navchalnoyi ta naukovoyi literatury $\mathrm{v}$ systemi profesiynoyi pidhotovky studentiv [Psychology of Academic and Scientific Literature Reading in the System of Students' Professional Training]. Extended abstract of Doctor's thesis. Kyiv: KDPI im. M.P. Drahomanova [in Ukrainian].

Shhipicina, L.Ju. (2011). Kompleksnaja lingvisticheskaja harakteristika kompjuternooposredovannoj kommunikacii (na materiale nemeckogo jazyka) [Complex linguistic characteristics of computer-mediated communication (based on the German language)]. Extended abstract of Doctor's thesis. Voronezh [in Russian].

Akimoto, Y., Takahashi, H., Gunji, A., Kaneko, Y., Asano, M., Matsuo, J. ... Yoko, Y. (2017). Alpha band event-related desynchronization underlying social situational context processing during irony comprehension: A magnetoencephalography source localization study. Brain and Language, 175, 42-46. https://doi. org/10.1016/j.bandl.2017.09.002

Bitan, T., Kaftory, A., Meiri-Leib, A., Eviatar, Z., \& Peleg, O. (2017). Phonological ambiguity modulates resolution of semantic ambiguity during reading: An fMRI study of Hebrew. Neuropsychology, 31(7), 759-777. https://doi.org/10.1016/j. bandl.2017.09.002

Bosco, F.M., \& Gabbatore, I. (2017). Theory of mind in recognizing and recovering communicative failures. Applied Psycholinguistics, 38(1), 57-88. https://doi. org/10.1017/S0142716416000047

Cummine, J., Cribben, I., Luu, C., Kim, E., Bakhtiari, R., Georgiou, G., \& Boliek, C.A. (2016). Understanding the role of speech production in reading: Evidence for a print-to-speech neural network using graphical analysis. Neuropsychology, 30(4), 385-397. https://doi.org/10.1037/neu0000236

De Freitas P.V., Peruzzi Ella Da Mota, M.M., \& Deacon, S.H. (2018). Morphological awareness, word reading, and reading comprehension in Portuguese. Applied Psycholinguistics, 39(3), 507-525. https://doi.org/10.1017/S0142716417000479

Foucart, A., Romero-Rivas, C., Gort, B.L., \& Costa, A. (2016). Discourse comprehension in L2: Making sense of what is not explicitly said. Brain and Language, 163, 32-41. https://doi.org/10.1016/j.bandl.2016.09.001

Giustolisi, B., Vergallito, A., Cecchetto, C., Varoli, E., \& Lauro, L.J. (2018). Anodal transcranial direct current stimulation over left inferior frontal gyrus enhances sentence comprehension. Brain and Language, 176, 36-41. https://doi. org/10.1016/j.bandl.2017.11.001

Graesser, A., Wiemer-Hastings, P. \& Wiemer-Hastings, K. (2001). Constructing Inferences and Relations during Text Comprehension. In Sanders, Schilperoord \& Spooren (Eds.), Text representation: Linguistic and Psycholinguistic Aspects (pp. 21-26). Amsterdam / Philadelphia: Benjamins. https://doi.org/10.1075/ hcp.8.14gra 
Вплив досвіду користування інтернетом на особливості...

Hahne, C., Goldhammer, F., Kröhne, U., \& Naumann, J. (2018). The role of reading skills in the evaluation of online information gathered from search engine environments. Computers in Human Behavior, 78, 223-234. https://doi. org/10.1016/j.chb.2017.10.004

Houghton, G. (2018). Action and perception in literacy: A common-code for spelling and reading. Psychological Review, 125(1), 83-116. https://doi.org/10.1037/ rev0000084

Hubers, F., Snijders, T., \& Hoop, H. (2016). How the brain processes violations of the grammatical norm: An fMRI study. Brain and Language, 163, 22-31. https://doi. org/10.1016/j.bandl.2016.08.006

Mason, L., Scrimin, S., Zaccoletti, S., Tornatora, M., \& Goetz, T. (2018). Webpage reading: Psychophysiological correlates of emotional arousal and regulation predict multiple-text comprehension. Computers in Human Behavior, 87, $317-$ 326. https://doi.org/10.1016/j.chb.2018.05.020

Ohadi, J., Brown, B., Trub, L., \& Rosenthal, L. (2018). I just text to say I love you: Partner similarity in texting and relationship satisfaction. Computers in Human Behavior, 78, 126-132. https://doi.org/10.1016/j.chb.2017.08.048

Sharon, E.M., \& Thompson-Schill, L. (2017). Tracking competition and cognitive control during language comprehension with multi-voxel pattern analysis. Brain and Language, 165, 21-32. https://doi.org/10.1016/j.bandl.2016.11.002

Van den Broek, P., Young, M., Tzeng, Y., \& Linderholm, T. (1999). The landscape model of reading. In H. van Oostendorp \& S.R. Goldman (Eds.), The Construction of Mental Representations During Reading (pp. 71-98). Mahwah, NJ: Erlbaum.

\section{АНОТАЦІЯ}

Мета дослідження. У статті представлені результати емпіричного дослідження значимості досвіду користування інтернетом у процесі розуміння текстів інтернету.

Методики дослідження. Використано теоретичні методи i методики: дедуктивний, індуктивний методи, аналіз та синтез, узагальнення, систематизацію; емпіричні методи: експеримент (семантизуючий та рецептивний), метод семантичних і прагматичних інтерпретацій, контентаналіз, процедуру суб'єктивного шкалування; математичні методи: первинної статистики, перевірки на нормальний характер розподілу даних, статистичного виводу, з врахуванням статистичних показників моди та розмаху варіації; а також низку інтерпретаційних методів, що грунтуються на конкретних принципах системного, діяльнісного, когнітивного та організаційного підходів.

Результати. Розуміння текстів інтернету суттєво відрізняється від розуміння усних чи друкованих текстів, оскільки текст інтернету $\epsilon$ прагматично чілісним електронним документом, що складається з умовно завершених текстових блоків у формі "вікон», які розкриваються в окремих вкладках браузера, порядок освоєння яких залежить як від гіперпосилань, так і від поведінки користувача. До особливостей текстів інтернету належать 
Impact of the Internet Using Experience on the Peculiarities...

посилені діалогічність, подільність, зовнішня інформативність, послаблені зв'язність і осмисленість, прагматична і переважно формальна чілісність, умовна завершеність, ускладнена структурність, а також гібридність i високий ступінь проникності, мультимедійність, презентативність, схильність до мовної гри і колективного авторства, насиченість неологізмами, емотиконами і скороченнями, фрагментарність, недотримання мовних норм, функціонування особливого мовленнєвого етикету.

Висновки. В результаті емпіричного дослідження за участю 716 респондентів з різних регіонів України було визначено, що досвід найбільш суттєво впливає на процес розуміння на етапі рецепиії, скеровуючи активність користувачів та точність їх очікувань. Досвід сприяє точності прогнозування змісту текстів інтернету в на 15\%. На етапі інтерпретації адекватність та повнота тлумачення текстів інтернету з накопиченням досвіду покращується майже на 10\%. Однак навіть досвідчені користувачі змогли вірно інтерпретувати лише чверть домінант, тоді як випадкові - лише шосту частину. Ще менше значення має рівень досвіду та інтернет-активності на етапі емоційної ідентифікації, ані оцінка зрозумілості, ані узгодженість емоційного ставлення майже не залежать від досвіду користування інтернетом. 3 накопиченням досвіду користувачі оцінюють тексти інтернету більш однорідно, їм легше вдається усвідомлювати власне ставлення до текстів інтернету, воно стає більш узгодженим, проте, як і недосвідчені читачі, вони більше ніж у половині випадків недооцінюють складність текстів інтернету, так само схильні поділяти тексти на схвальні та критичні.

Ключові слова: розуміння, текст інтернету, сприйняття, інтерпретація, емочійна ідентифікація, досвід, інтернет-активність.

\section{Акимова Наталья, Александренко Екатерина. Влияние опыта пользования интернетом на особенности понимания текстов интернета}

\section{АННОТАЦИЯ}

Цель исследования. В статье представлены результаты эмпирического исследование значимости опыта пользования интернетом в процессе понимания текстов интернета.

Методики исследования. Использованы теоретические методы и методики: дедуктивный, индуктивный методы, анализ и синтез, обобщение, систематизация; эмпирические методы: эксперимент (семантизирующий и рецептивный), метод семантических и прагматических интерпретаций, контент-анализ, процедура субъективного шкалирования; математические методы: первичной статистики, проверки на нормальный характер распределения данных, статистического вывода, с учетом статистических показателей моды и размаха вариации; а также ряд интерпретационных методов, основанных на конкретных принципах системного, деятельностного, когнитивного и организационного подходов. 
Вплив досвіду користування інтернетом на особливості...

Результаты. Автор отмечает, что понимание текстов интернета существенно отличается от понимания устных или печатных текстов, поскольку текст интернета является прагматично целостным электронным документом, состоит из условно завершенных текстовых блоков в форме "окон», раскрывающихся в отдельных вкладках браузера, порядок освоения которых зависит как от гиперссылок, так и от поведения пользователя. К особенностям текстов интернета принадлежат усиленные диалогичность, делимость, внешняя информативность, ослабленые связность и осмысленность, прагматичная и преимущественно формальная целостность, условная завершенность, осложненная структурность, а также гибридность и высокая степень проницаемости, мультимедийность, презентативность, склонность к языковой игре и коллективному авторству, насыщенность неологизмами, эмотиконами и сокращениями, фрагментарность, несоблюдение языковых норм, функционирование особого речевого этикета.

Выводы. В результате эмпирического исследования с участием 716 респондентов из разных регионов Украины было определено, что опыт наиболее существенно влияет на процесс понимания на этапе рецепции, направляя активность пользователей и точность их ожиданий. Опыт способствует точности прогнозирования содержания текстов интернета в 15\%. На этапе интерпретации адекватность и полнота толкования текстов интернета с накоплением опыта улучшается почти на 10\%. Однако даже опытные пользователи смогли верно интерпретировать только четверть доминант, тогда как случайные - только шестую часть. Еще меньшее значение имеет уровень опыта и интернет-активности на этапе эмоциональной идентификации, ни оценка понятности, ни согласованность эмоционального отношения почти не зависят от опыта пользования интернетом. С накоплением опыта пользователи оценивают тексты интернета более однородно, им легче удается осознавать собственное отношение к текстам интернета, оно становится более согласованным, однако, как и неопытные читатели, они больше чем в половине случаев недооценивают сложность текстов интернета, так же склонны разделять тексты на позитивные и критические.

Ключевые слова: понимание, текст интернета, восприятие, интерпретация, эмоциональная идентификация, опыт, интернет-активность. 